Int. J. Morphol.,

33(2):647-652, 2015

\title{
IRF6, RYK, and PAX9 Expression in Facial Tissue of Children with Cleft Palate
}

\author{
Expresión de IRF6, RYK y PAX9 en el Tejido Facial de Niños con Paladar Fisurado
}

\author{
Liene Smane* \& Mara Pilmane*
}

\begin{abstract}
SMANE, L. \& PILMANE, M. IRF6, RYK, and PAX9 expression in facial tissue of children with cleft palate. Int. J. Morphol., 33(2):647-652, 2015.

SUMMARY: Cleft lip and palate (CLP) is a congenital anomaly characterized by the inappropriate fusion of the upper lip, alveolus, and secondary palate. This study investigated whether expression of interferon regulatory fac tor 6 (IRF6), receptor-like tyrosine kinase (RYK), and paired-box 9 (PAX9), which are essential for the normal development and morphogenesis of craniofacial structures, is dysregulated in children with CLP. Oral mucosa tissue samples were obtained from patients with complete bilateral (CB) CLP ( $\mathrm{n}=19)$ during corrective plastic surgery and unaffected control subjects $(n=7)$. IRF6, RYK, and PAX9 expression was assessed by immunohistochemistry, and data were analyzed with the Mann-Whitney test. In patients, IRF6 immunoreactivity in the connective tissue was moderate to high, but the overall number of IRF6-positive oral epithelial cells was lower than that in controls $(\mathrm{z}=-3.41 ; \mathrm{P}=0.01)$. RYK expression was observed only sporadically in the oral epithelium of 4 patients, in contrast to the control group $(\mathrm{z}=-3.75 ; \mathrm{P}<0.001)$. PAX9-positive epithelial cells were present in low to moderate numbers in patients with CBCLP, while an abundance of these cells was observed in the basal layer of the oral epithelium in controls $(\mathrm{z}=-3.60 ; \mathrm{P}<0.001)$. IRF6 is the main connective tissue regulatory factor in CBCLP, and its low level of expression in the oral epithelium suggests a reduced potential for epitheliocyte differentiation, while low PAX9 and RYK expression may explain the decreased cell migration and cleft remodeling in CBCLP.
\end{abstract}

KEY WORDS: Cleft palate; Interferon regulatory factor 6; Receptor-like tyrosine kinase; Paired box gene 9.

\section{INTRODUCCIÓN}

Cleft lip and palate (CLP) is the fourth most common birth defect and most common congenital malformation of the head and neck in humans, occurring in 1 in 600 European children. CLP is characterized by the incomplete formation of structures separating the nasal and oral cavities including the lip, alveolus, and hard and soft palates, with the most severe clefts extending completely through both soft tissue and bone. To date, little is known of the etiopathogenesis of CLP; however, various genetic and environmental factors have been implicated (Mossey \& Modell, 2012).

No single gene known to cause CLP has been identified thus far, although more than 20 candidate genes have been proposed based on animal studies and linkage analysis in human families (Setó-Salvia \& Stanier, 2014). Early development of the orofacial complex is mediated by epithelial-mesenchymal interactions and depends on a wide range of signaling molecules including bone morphogenetic proteins and transforming and fibroblast growth factors, as well as transcription factors belonging to the paired box (Pax), Msx homeobox, and interferon regulatory factor (Irf) gene families (Rahimov et al., 2012).

Pax proteins play an essential role in organogenesis during embryonic development in regulating cell proliferation, self-renewal, resistance to apoptosis, and migration of embryonic precursor cells. One family member, Pax9, is widely expressed in the neural crest-derived mesenchyme where it increases mesenchymal cell proliferation during embryogenesis (Chi \& Epstein, 2002). Pax9 is also expressed in the epithelium of the oral cavity, regulating several aspects of epitheliocyte differentiation, and is essential for lip development and palate growth (Nakatomi et al., 2010).

The Irf6 gene is strongly associated with the risk of developing oral-facial clefts (Wu-Chou et al., 2013). IRF6 is a key factor in oral and maxillofacial development,

* Institute of Anatomy and Anthropology, Department of Morphology, Riga Stradins University, Riga, Latvia. This study was funded by the Support for Doctoral and Post-doctoral Investigations Riga Stradins University fellowship (Nr.2009/0147/1DP/1.1.2.1.2/ 09/IPIA/VIAA/009) and RSU project "Longitudinal research on cleft morphopathogenesis". 
regulating facial fusion via modulation of epithelial cell proliferation and differentiation. Nonetheless, IRF6mediated molecular pathways involved in lip and palate development are poorly characterized. Disrupting Irf6 function in mice results in clefting phenotypes (Ingraham $e t$ al., 2006), and many studies have provided evidence suggesting a role for Irf6 in the etiology of CLP (Lu et al., 2013; Song et al., 2013).

Receptor tyrosine kinase (Ryk) has also been implicated in cases of CLP. RYK is an orphan receptor glycoprotein with transmembrane, $\mathrm{N}$-terminal extracellular ligand-binding, and C-terminal intracellular tyrosine kinase domains (Halford \& Stacker, 2001). Ryk is essential for the normal development and morphogenesis of craniofacial structures. Its widespread expression, both in developing and adult tissues, suggests involvement in many essential biological processes including cell differentiation, polarity, migration, and target selection. The precise function of RYK is not known; however, Ryk polymorphism is a genetic risk factor for cleft lip and palate (Watanabe et al., 2006).

This study investigated the expression of IRF6, RYK, and PAX9 in complete bilateral (CB) CLP to identify possible changes in signaling pathways that could lead to the aberrant maxillofacial morphogenesis observed in CLP.

\section{MATERIALS AND METHODS}

Study population. Samples were collected from the Cleft Lip and Palate Centre at the Institute of Stomatology of Riga Stradins University from 19 patients with CBCLP and 7 unaffected control subjects. The patient group comprised 14 males and 5 females. Samples of oral mucosa were collected during surgical cleft correction from children ranging in age from 3 months to 8 years and 5 months, or upon tooth extraction from control subjects ranging in age from 6 years to 9 years The study was performed according to the principles of the Declaration of Helsinki, and the protocol was independently reviewed and approved by the Ethical Committee of Riga Stradins University (2003). Written, informed consent was obtained from the parents of all participants after the nature of the study had been fully explained.

Tissue sample preparation. For conventional light microscopy and immunohistochemistry, the tissue specimens were fixed for 1 day in a mixture of $2 \%$ formaldehyde and $0.2 \%$ picric acid in $0.1 \mathrm{M}$ phosphate buffer $(\mathrm{pH}$ 7.2). They were then rinsed in thyroid buffer containing $10 \%$ saccharose for $12 \mathrm{~h}$ and embedded in paraffin. Each block was cut into
4- $\mu \mathrm{m}$ sections that were mounted on glass slides, deparaffinized, rehydrated through a graded alcohol series, and stained with hematoxylin and eosin.

Immunohistochemistry. Tissue sections were labeled with the following primary antibodies: rabbit anti-IRF6 at 1:100 (167403; Abcam, Burlingame, CA, USA), mouse anti-PAX9 at 1:100 (sc-56823; Santa Cruz Biotechnology, Inc., Santa Cruz, CA, USA), and rabbit anti-RYK at 1:50 (orb38371; Biorbyt, San Francisco, CA, USA). The signal was visualized by biotin-streptavidin immunohistochemistry (Hsu et al., 1981). Images were captured using a DC 300F camera (Leica, Wetzlar, Germany) and the image processing and analysis software Image Pro Plus v.6.0 (Media Cybernetics, Silver Spring, MD, USA). The intensity of immunostaining was graded semi-quantitatively on a scale of 0 to ++++ , as follows: 0 , no positive structures; $0 /+$, occasional positive structures; + , few immunoreactive structures; ++ , a moderate number of immunoreactive structures; +++ , numerous immunoreactive structures; and ++++ , an abundance of immunoreactive structures in the visual field (Pilmane et al., 1998). The localization of staining was assessed at both tissue and cellular levels.

Statistical analysis. Statistical analyses were performed using SPSS v.20.0 (IBM Corp., Armonk, NY, USA). Results are expressed as Mean \pm SD. A Mann-Whitney test was used to compare groups and a $\mathrm{P}$ value $<0.05$ was considered statistically significant.

\section{RESULTS}

PAX9-positive structures were detected in all CBCLP cases, and the presence of PAX9-positive epithelial cells was occasional to moderate (Fig. 1). PAX9 immunoreactivity was observed in epitheliocytes, sweat glands, and outer epithelial sheaths of hair follicles (Fig. 2). In all control specimens, an abundance of PAX9-positive cells was seen in the oral epithelium, especially in the basal cell layer (Fig. 3). The total number of PAX9-positive epithelial cells was significantly lower in the CBCLP than in the control group $(\mathrm{z}=-3.60 ; \mathrm{P}<$ 0.001 ).

IRF6-positive structures were present in all soft tissue samples, and immunoreactivity was detected in epithelial cells, fibroblasts, and macrophages (Fig. 4). The number of IRF6positive connective cells varied from moderate to abundant in all CBCLP cases but positive epitheliocytes were seen in a few to moderate number of positive structures. There was significant difference between the groups in the mean numbers of IRF6-positive epithelial cells $(\mathrm{z}=-3.41 ; \mathrm{P}=0.01)$. 


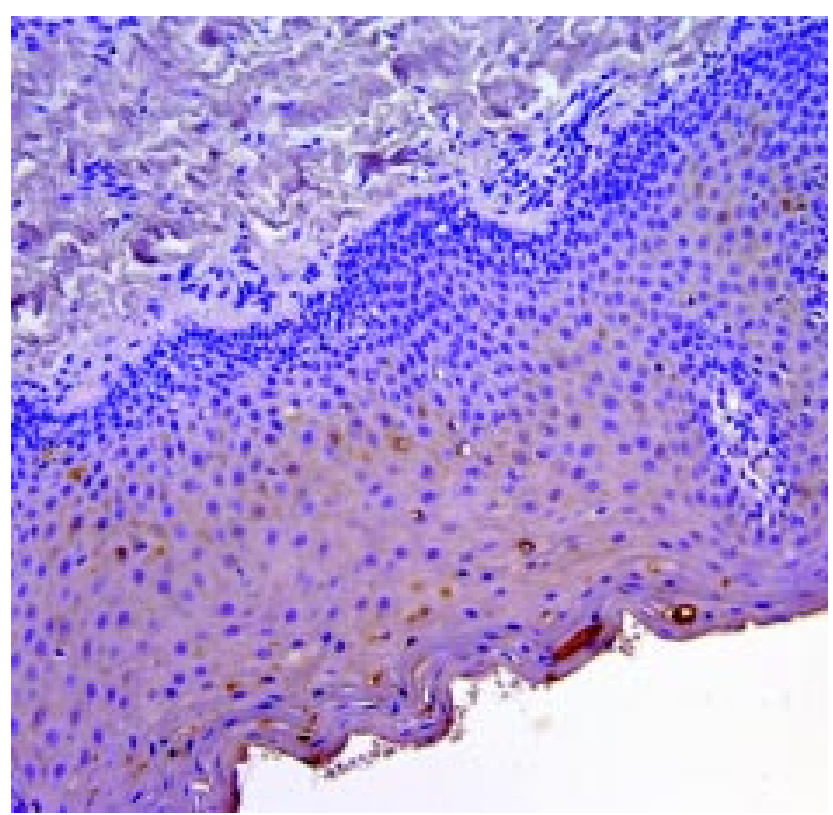

Fig. 1. Moderate PAX9 immunoreactivity in oral epithelial cells from the lip tissue of a 3-month-old child with CBCLP. 200¥ magnification.

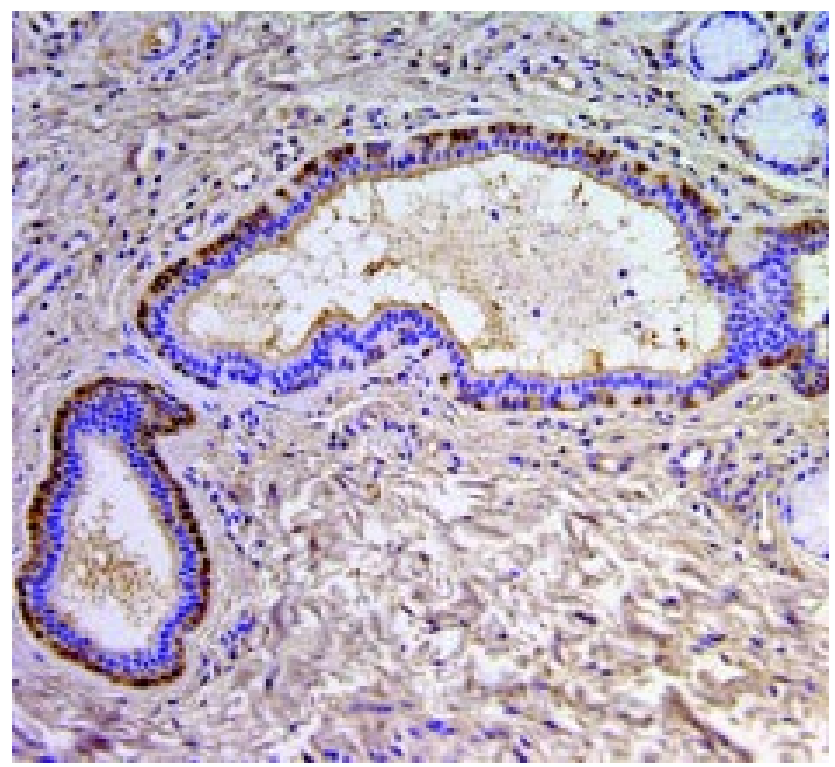

Fig. 2. Abundant PAX9 immunoreactivity in sweat gland cells from lip tissue of a 6-month-old child with CBCLP. 400¥ magnification.

Of the 19 CBCLP specimens, 15 were negative for RYK, although the signal was detected in a few cells in both patients and controls, with no significant difference between them $(\mathrm{z}=-3.75 ; \mathrm{P}<0.001)$. Few RYK-positive epithelial cells were present in CBCLP specimens (Fig. 5), and there was no signal present in other structures of the oral mucosa.

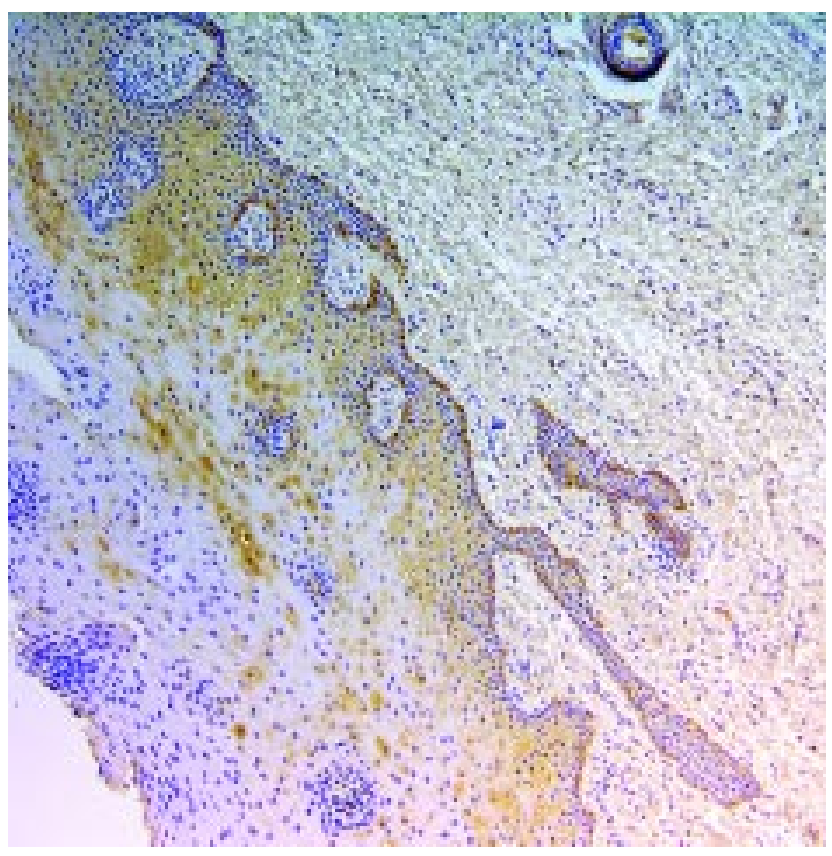

Fig. 3. Abundant PAX9 immunoreactivity oral epithelial cells of the basal cell layer in tissue from an unaffected 6-years-old child. $100 ¥$ magnification.

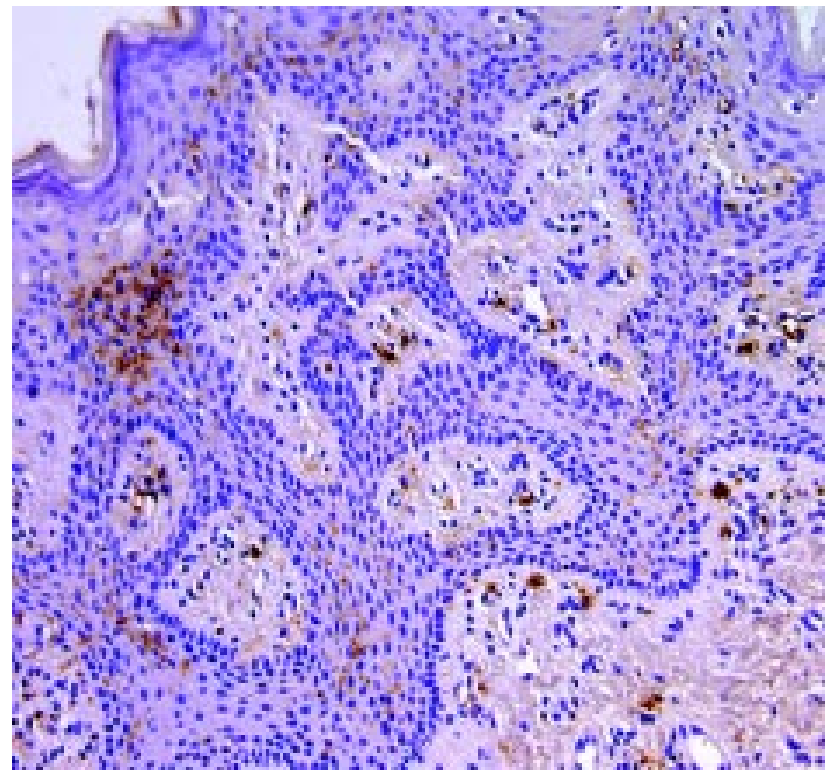

Fig. 4. Moderate IRF6 immunoreactivity in oral epithelial and connective tissue cells from the cleft lip tissue of a 3-month-old child. 200¥ magnification.

\section{DISCUSSION}

The formation of the upper lip and palate is a complex process of cell proliferation, differentiation, adhesion, and apoptosis involving highly coordinated steps during 


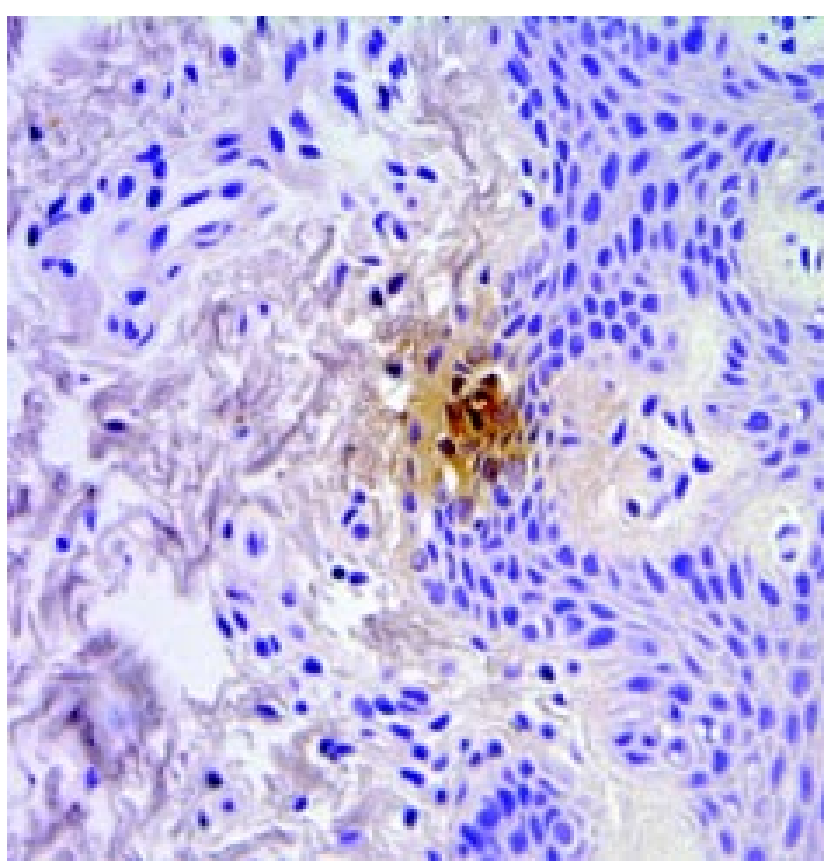

Fig. 5. Sporadic RYK immunoreactivity in oral epithelial cells from the cleft lip tissue of a 3-month-old child. 250¥ magnification.

embryonic development that are strictly controlled by gene regulatory networks. In theory, failure at any step in the process can lead to clefts (Jiang et al., 2006); abnormal facial tissue development during gestation is the result of interactions between genetic and environmental factors. Lip development precedes palate formation, and therefore improper lip fusion may secondarily affect palate fusion. Thus, a cleft lip and palate often occur concurrently (Meng et al., 2009). Pax9 is essential for lip and secondary palate formation, and is required to regulate the normal shape of palatal shelves (Peters et al., 1998).

Genetic studies in humans have suggested a role for Pax9 in the pathogenesis of CLP (Sasaki et al., 2007; Hamachi et al., 2003; Küchler et al., 2014), but the results have been inconclusive. PAX9-positive cell distribution varied from occasional to numerous positive structures in the patients examined, and PAX9 expression in the oral mucosa was lower in the CBCLP compared to the control group. These results suggest an involvement of Pax9 in cell proliferation, resistance to apoptosis, and/or cell migration during palate formation. Supporting this conjecture, a previous study showed only occasional apoptotic cells in CBCLP-affected soft tissue, while an abundance of cells undergoing apoptosis was seen in samples from a control group (Smane et al., 2013).

Irf6 has been implicated in the development of cleft lip and palate, but the changes in Irf6 expression or function that produce the defect have not yet been defined. Research in animal models has indicated that IRF6 regulates epitheliocyte proliferation and has a key role in formation of the oral periderm. Irf6 is expressed in the facial primordium prior to and during morphogenesis of the primary palate (Washbourne \& Cox, 2006), and preliminary findings in mice have revealed Irf6 expression in the medial edge epithelia of fusing secondary palatal shelves, tooth buds, hair follicles, and skin (Kondo et al., 2002). While Irf6 is presumed to have a role in CBCLP, there has been no evidence in support of this possibility, although a study established a link between Irf6 and the etiology of nonsyndromic CLP in populations of European ancestry (Carinci et al., 2007). In the present study, elevated IRF6 expression was observed in fibroblasts and macrophages in connective tissue from patients with CBCLP. In contrast, there were fewer IRF6-positive epitheliocytes in tissue samples from patients with CBCLP than from unaffected individuals.

It was also previously demonstrated that RYK is involved in the development of cleft lip and/or palate. Although essential for the morphogenesis of craniofacial structures, Ryk has not been extensively studied in the context of CBCLP. Protein localization studies and in situ hybridization have indicated that Ryk is broadly expressed in both the embryo and adult, and mouse embryos deficient in Ryk have craniofacial defects, including complete clefts, as well as skeletal defects (Halford et al., 2000). In this study, RYK expression was downregulated in CBCLP tissue compared to control tissue, providing evidence for the involvement of Ryk in the pathogenesis of CBCLP.

\section{CONCLUSIONS}

The results of this study suggest that IRF6 is the main factor expressed in connective tissues of the oral mucosa, and the downregulation of IRF6 in the oral epithelium of CBCLP cases indicates that it may be responsible for a decrease in the differentiation potential of epitheliocytes in CLP. The reduced expression of PAX9 and RYK in CBCLP tissues also implicates these factors in the dysregulation of cell migration and tissue remodeling during cleft morphogenesis.

\section{ACKNOWLEDGMENTS}

We acknowledge D.D.S., MSc (Oslo), Ph.D., Prof. Ilze Akota from Institute of Stomatology, Riga Stradins University, Latvia for supplying of patients material. 
SMANE, L. \& PILMANE, M. Expresión de IRF6, RYK y PAX9 en el tejido facial de niños con paladar fisurado. Int. J. Morphol., 33(2):647-652, 2015.

RESUMEN: La fisura labial y palatina (FLP) son anomalías congénitas caracterizadas por la fusión inadecuada del labio superior, alvéolo y paladar secundario. En este estudio se investigó si en niños con FLP hay una desregulación de la expresión del factor regulador de interferón 6 (IRF6), del receptor de la tirosina quinasa (RYK), y del factor de transcripción PAX9, que son esenciales para el desarrollo normal y la morfogénesis de las estructuras craneofaciales. Se obtuvieron muestras de la mucosa oral de pacientes con FLP completa bilateral (CB) $(n=$ 19), tomadas durante la realización de cirugía plástica correctiva, y de sujetos de control no afectados $(n=7)$. Se evaluó la expresión de IRF6, RYK y PAX9 por inmunohistoquímica, y los datos se analizaron con la prueba de Mann-Whitney. En los pacientes, la inmunoreactividad de IRF6 en el tejido conectivo fue de moderada a alta, pero el número total de células epiteliales orales positivas para IRF6 fue menor que en los controles $(\mathrm{z}=-3,41 ; \mathrm{P}=$ 0,01). La expresión de RYK se observó sólo esporádicamente en el epitelio oral de 4 pacientes, en contraste con el grupo control $(\mathrm{z}=-3,75 ; \mathrm{P}<0.001)$. Células epiteliales positivas para PAX9 estaban presentes en números bajos a moderados en pacientes con FLP completa bilateral, mientras que se observó una abundante cantidad de estas células en la capa basal del epitelio oral en los controles $(\mathrm{z}=-3,60 ; \mathrm{P}<0,001)$. IRF6 es el principal factor regulador del tejido conectivo con FLP completa bilateral, y su bajo nivel de expresión en el epitelio oral sugiere un potencial reducido para la diferenciación del epitelio, mientras que la expresión baja de PAX9 y RYK pueden explicar la disminución de la migración celular y la remodelación de la fisura con FLP completa bilateral.

PALABRAS CLAVE: Fisura palatina; Factor regulador de interferón 6; Receptor de la tirosina quinasa; Factor de transcripción PAX9.

\section{REFERENCES}

Carinci, F.; Scapoli, L.; Palmieri, A.; Zollino, I. \& Pezzetti, F. Human genetic factors in nonsyndromic cleft lip and palate: an update. Int. J. Pediatr. Otorhinolaryngol., 71(10):1509-19, 2007.

Chi, N. \& Epstein, J. A. Getting your Pax straight: Pax proteins in development and disease. Trends Genet., 18(1):41-7, 2002.

Ingraham, C. R.; Kinoshita, A.; Kondo, S.; Yang, B.; Sajan, S.; Trout, K. J.; Malik, M. I.; Dunnwald, M.; Goudy, S. L.; Lovett, M.; Murray, J. C. \& Schutte, B. C. Abnormal skin, limb and craniofacial morphogenesis in mice deficient for interferon regulatory factor 6 (Irf6). Nat. Genet., 38(11):1335-40, 2006.

Halford, M. M. \& Stacker, S. A. Revelations of the RYK receptor. Bioessays, 23(1):34-45, 2001.
Halford, M. M.; Armes, J.; Buchert, M.; Meskenaite, V.; Grail, D.; Hibbs, M. L.; Wilks, A. F.; Farlie, P. G.; Newgreen, D. F.; Hovens, C. M. \& Stacker, S. A. Ryk-deficient mice exhibit craniofacial defects associated with perturbed Eph receptor crosstalk. Nat. Genet., 25(4):414-8, 2000.

Hamachi, T.; Sasaki, Y.; Hidaka, K. \& Nakata, M. Association between palatal morphogenesis and Pax9 expression pattern in CL/Fr embryos with clefting during palatal development. Arch. Oral. Biol., 48(8):581-7, 2003.

Hsu, S. M.; Raine, L. \& Fanger, H. The use of antiavidin antibody and avidin-biotin-peroxidase complex in immunoperoxidase technics. Am. J. Clin. Pathol., 75(6):816-21, 1981.

Jiang, R.; Bush, J. O. \& Lidral, A. C. Development of the upper lip: morphogenetic and molecular mechanisms. Dev. Dyn., 235(5):1152-66, 2006.

Küchler, E. C.; Sabóia, T. M.; Vieira, T. C.; Lips, A.; Tannure, P. N.; Deeley, K.; Reis, M. F.; Ho, B.; Rey, A. C.; Costa, M. C.; Granjeiro, J. M. \& Vieira, A. R. Studies of genes involved in craniofacial development and tumorigenesis: FGF3 contributes to isolated oral clefts and may interact with PAX9. Acta Odontol. Scand., 72(8):1070-8, 2014.

Kondo, S.; Schutte, B. C.; Richardson, R. J.; Bjork, B. C.; Knight, A. S.; Watanabe, Y.; Howard, E.; de Lima, R. L.; DaackHirsch, S.; Sander, A.; McDonald-McGinn, D. M.; Zackai, E. H.; Lammer, E. J.; Aylsworth, A. S.; Ardinger, H. H.; Lidral, A. C.; Pober, B. R.; Moreno, L.; Arcos-Burgos, M.; Valencia, C.; Houdayer, C.; Bahuau, M.; Moretti-Ferreira, D.; Richieri-Costa, A.; Dixon, M. J. \& Murray, J. C. Mutations in IRF6 cause Van der Woude and popliteal pterygium syndromes. Nat. Genet., 32(2):285-9, 2002.

Lu, Y.; Liu, Q.; Xu, W.; Li, Z.; Jiang, M.; Li, X.; Zhao, N.; Liu, W.; Sui, Y.; Ma, C.; Feng, W.; Han, W. \& Li, J. TGFA and IRF6 contribute to the risk of nonsyndromic cleft lip with or without cleft palate in northeast China. PLoS One, 8(8):e70754, 2013.

Meng, L.; Bian, Z.; Torensma, R. \& Von den Hoff, J. W. Biological mechanisms in palatogenesis and cleft palate. J. Dent. Res., 88(1):22-33, 2009.

Mossey, P. A. \& Modell, B. Epidemiology of oral clefts 2012: an international perspective. Front. Oral Biol., 16:1-18, 2012.

Nakatomi, M.; Wang, X. P.; Key, D.; Lund, J. J.; Turbe-Doan, A.; Kist, R.; Aw, A.; Chen, Y.; Maas, R. L. \& Peters, H. Genetic interactions between Pax9 and Msx 1 regulate lip development and several stages of tooth morphogenesis. Dev. Biol., 340(2):438-49, 2010.

Peters, H.; Neubüser, A.; Kratochwil, K. \& Balling, R. Pax9deficient mice lack pharyngeal pouch derivatives and teeth and exhibit craniofacial and limb abnormalities. Genes Dev., 12(17):2735-47, 1998. 
Pilmane, M.; Rumba, I.; Sundler, F. \& Luts, A. Patterns of distribution and occurrence of neuroendocrine elements in lungs of humans with chronic lung diseases. Proc. Latv. Acad. Sci. B, 52:144-52, 1998.

Rahimov, F.; Jugessur, A. \& Murray, J. C. Genetics of nonsyndromic orofacial clefts. Cleft Palate Craniofac. J., 49(1):73-91, 2012.

Sasaki, Y.; O’Kane, S.; Dixon, J.; Dixon, M. J. \& Ferguson, M. W. Temporal and spatial expression of Pax9 and Sonic hedgehog during development of normal mouse palates and cleft palates in TGF-beta3 null embryos. Arch. Oral. Biol., 52(3):2607, 2007.

Setó-Salvia, N. \& Stanier, P. Genetics of cleft lip and/or cleft palate: association with other common anomalies. Eur. J. Med. Genet., 57(8):381-93, 2014.

Smane, L.; Pilmane, M. \& Akota, I. Apoptosis and MMP-2, TIMP-2 expression in cleft lip and palate. Stomatologija, 15(4):129-34, 2013.

Song, T.; Wu, D.; Wang, Y.; Li, H.; Yin, N. \& Zhao, Z. SNPs and interaction analyses of IRF6, MSX1 and PAX9 genes in patients with non-syndromic cleft lip with or without palate. Mol. Med. Rep., 8(4):1228-34, 2013.

Washbourne, B. J. \& Cox, T. C. Expression profiles of cIRF6, cLHX6 and cLHX7 in the facial primordia suggest specific roles during primary palatogenesis. B. M. C. Dev. Biol., 6:18, 2006.

Watanabe, A.; Akita, S.; Tin, N. T.; Natsume, N.; Nakano, Y.; Niikawa, N.; Uchiyama, T. \& Yoshiura, K. A mutation in RYK is a genetic factor for nonsyndromic cleft lip and palate. Cleft Palate Craniofac. J., 43(3):310-6, 2006.

Wu-Chou, Y. H.; Lo, L. J.; Chen, K. T.; Chang, C. S. \& Chen, Y. R. A combined targeted mutation analysis of IRF6 gene would be useful in the first screening of oral facial clefts. B. M. C. Med. Genet., 14:37, 2013.
Correspondence to:

Liene Smane

Institute of Anatomy and Anthropology

Riga Stradins University

Dzirciema Street 16

Riga LV 1007

LATVIA

Email: Liene.Smane@rsu.Iv

Received: 22-01-2015

Accepted: 15-04-2015 